\title{
PENGARUH BAURAN PROMOSI DAN HARGA TERHADAP KEPUTUSAN PEMBELIAN PRODUK KOSMETIK MAYBELLINE DI KOTA PADANG
}

\author{
Ade Candra Gunawan, Febsri Susanti \\ Sekolah Tinggi Ilmu Eknomi "KBP" \\ febsrisusanti@akbpstie.ac.id
}

\begin{abstract}
ABSTRAK
Tujuan dari penelitian ini adalah untuk mengetahui dan menganalisis pengaruh periklanan, personal selling dan harga terhadap keputusan pembelian produk kosmetik Maybelline di Kota Padang. Teknik sampling yang digunakan adalah purposive sampling, sedangkan jumlah sampel yang digunakan untuk analisis adalah 100 orang. Teknik analisis data yang digunakan untuk menguji hipotesis adalah regresi linier berganda. Dalam penelitian ini terdapat tiga variabel bebas, yaitu periklanan, personal selling dan harga. Variabel yang memiliki pengaruh signifikan terhadap keputusan pembelian produk kosmetik Maybelline di Kota Padang adalah periklanan dan personal selling. Sedangkan nilai koefisien determinasi dalam penelitian ini ditemukan sebesar 0,896, atau sama dengan 89,6\%. Hasil tersebut memperlihatkan bahwa dari keputusan pembelian produk kosmetik Maybelline di Kota Padang yang dapat dijelaskan oleh periklanan, personal selling dan harga sebesar $89,6 \%$, sedangkan 10,4\% diduga dijelaskan oleh faktor-faktor lain yang tidak diteliti dalam penelitian ini, seperti distribusi, serta psikologi konsumen yang terdiri dari motivasi, persepsi, pembelajaran, keyakinan dan sikap serta citra merek. Berdasarkan hasil pengujian analisis regresi linier berganda, ditemukan bahwa variabel periklanan, personal selling dan harga berpengaruh positif terhadap keputusan pembelian produk kosmetik Maybelline di Kota Padang. Penelitian ini memberikan rekomendasi praktis untuk manajemen Maybelline Padang untuk terus berupaya meningkatkan periklanan dan personal selling di masa yang akan datang. Hal ini disebabkan karena periklanan dan personal selling memiliki pengaruh yang berarti terhadap keputusan pembelian produk kosmetik Maybelline di Kota Padang.
\end{abstract}

Kata Kunci : $\quad$ Periklanan, Personal selling, Harga dan Keputusan Pembelian

PENDAHULUAN

Persaingan antar pasar industri perawatan pribadi dan kosmetik semakin kompetitif. Hal ini terbukti dengan banyaknya jenis kosmetika beredar baik produksi dalam negeri maupun produksi luar negeri. Membanjirnya produk kosmetika di pasaran mempengaruhi sikap seseorang terhadap keputusan pembelian dan pemakaian barang. Pembelian suatu produk bukan lagi untuk memenuhi kebutuhan (need), 
melainkan karena keinginan (want). Ditambah dengan ditemukannya konsumen memutuskan memilih menggunakan produk tertentu (kosmetika) dalam rangka memperjelas identitas diri agar dipandang baik dalam komunitas tertentu.

Kosmetik merupakan produk yang unik karena selain memiliki kemampuan untuk memenuhi kebutuhan mendasar wanita akan kecantikan. Seringkali menjadi sarana bagi konsumen untuk memperjelas identitas dirinya secara sosial dimata masyarakat. Seiring perkembangan zaman, kosmetik seolah menjadi kebutuhan primer bagi sebagian kaum wanita. Kosmetik merupakan salah satu kebutuhan yang sangat penting bagi seorang wanita. Disadari atau tidak, dalam kesehariannya wanita tidak bisa lepas dari kosmetik. Produk perawatan tubuh ini digunakan oleh sebagian besar wanita mulai dari pagi hari hingga malam hari. Oleh karena itu, banyak perusahaan yang berusaha memenuhi kebutuhan akan kosmetik dengan berbagai macam inovasi produk.

Produk kosmetik yang sudah mendunia seperti The Maybelline yang begitu familiar di telinga juga tersebar di Indonesia. Maybelline merupakan salah satu merek kosmetik luxury yang berasal dari New York dengan omset miliaran dolar per tahun. Produk Maybelline yang kini ada dalam setiap pasar pengecer termasuk drugstores, toko, supermarket dan toko khusus kosmetik. Maybelline menggabungkan unsur-unsur seperti ukuran, gaya, warna dan keberhasilan yang memberikan rasa menawan pada wajah. Maybelline adalah produk kosmet ik internasional yang didirikan pada tahun 1915 oleh T.L. Williams di New York, Amerika Serikat.

Berdasarkan sumber data yang diperoleh dari Top Brand, dapat dilihat bahwa Revlon, Maybelline, Oriflame dan Wardah produk mereka saling bersaing dalam penjualannya. Namun pada Wardah sendiri sudah banyak di kenal oleh masyarakat Indonesia, hal tersebut terbukti dari nilai Top Brand Index yang diperoleh jauh lebih tinggi dari pesaing. Berbeda dengan Maybelline, setelah penulis amati penulis melihat data penjualan Maybelline di kota Padang selama tiga bulan terakhir di tahun 2017 bahwa terjadi penurunan penjualan.

Disamping itu, keputusan pembelian konsumen merupakan hal yang penting dalam hal kemajuan perusahaan, karena dengan semakin besar konsumen ingin membeli produk atau jasa dalam sebuah perusahaan, maka akan semakin besar peluang perusahaan tersebut untuk mendapatkan profit dan pelanggan tetap. Keputusan pembelian tidak hanya dapat menjadi peluang bagi perusahaan untuk mendapatkan keuntungan dari segi bisnis, namun juga dengan semakin banyaknya konsumen membeli suatu produk, maka perusahaan tersebut akan dikenal oleh banyak orang dan juga konsumen akan loyal kepada perusahaan tersebut. Untuk membuat seseorang memutuskan membeli produk yang perusahaan berikan, banyak cara yang bisa dicapai oleh perusahaan misalnya dengan memberikan kualitas terbaik dari produk itu sendiri.

Keputusan pembelian menurut Sciffman dan Kanuk (2008:485), dapat diartikan sebagai pemilihan dari dua atau lebih alternatif pilihan keputusan pembelian. Artinya bahwa seseorang sebelum melakukan pembelian tersedia beberapa alternatif pilihan, sehingga dia harus memilih salah satu diantaranya. Menurut Kotler dan Keller (2009:356) keputusan pembelian dipengaruhi oleh rangsangan pemasaran yang terdiri dari produk, harga, distribusi, dan promosi. Selanjutnya, Promosi adalah salah satu bentuk komunikasi pemasaran, sedangkan yang dimaksud dengan komunikasi pemasaran adalah aktifitas pemasaran yang berusaha menyebarkan informasi, mempengaruhi atau membujuk, dan kemudian mengingatkan pasar sasaran atas perusahaan dan produknya, agar bersedia menerima, membeli, dan setia pada produk yang ditawarkan oleh perusahaan yang bersangkutan.

Berkaitan dengan hal tersebut, produk kosmetik Maybelline dalam merangsang keinginan konsumen dalam melakukan pembelian adalah dengan melaksanakan 
kegiatan promosi yang diantaranya periklanan pada media brosur, surat kabar, majalah, dan televisi. Agar kegiatan promosi perusahaan dapat mencapai sasaran, harus dibuat perencanaan terlebih dahulu. Perencanaan dibuat dengan mempertimbangkan faktor-faktor yang terkait dengan kegiatan ini, sehingga promosi perusahaan dapat mencapai sasaran yang diinginkan.

Dengan bauran promosi yang diberikan maka keputusanpembelian akan sangat besar, karena perusahaan dapat memperkenalkan produk-produknya, membujuk, menyarankan serta menyakinkan konsumen untukmembeli produk yang akan ditawarkan. Apabila perusahaan melakukan kegiatanbauran promosi yang tepat dan efektif maka konsumen akan dapat lebih banyakmnegtahui produk yang ditawarkan sehingga kemungkinan konsumen untukmemutuskan membeli terhadap produk tersebut lebih besar.

Selain itu, kebijakan harga sangat menentukan dalam pemasaran sebuah produk, karena harga adalah satu-satunya unsur bauran pemasaran yang memberikan pendapatan bagi organisasi atau perusahaan. Jadi, tidak dapat dipungkiri bahwa harga merupakan suatu unsur penting, baik bagi perusahaan dalam mempengaruhi konsumen maupun bagi perusahaan dapat bertahan dalam persaingan (Kotler dan Keller, 2009). Harga dapat mempengaruhi kinerja finansial dan memiliki pengaruh penting terhadap persepsi pembeli. Harga merupakan segala bentuk biaya moneter yang dikorbankan oleh konsumen untuk memperoleh, memiliki, memanfaatkan sejumlah kombinasi dari barang beserta pelayanan dari suatu produk.

Harga merupakan hal penting, karena setiap harga yang ditetapkan perusahaan akan mengakibatkan tingkat permintaan terhadap produk berbeda. Dalam hal ini produk kosmetik Maybelline memberi gambaran bahwa secara bertahap, harga produk kosmetik mereka semakin hari semakin kompetitif. Jika harga yang diterapkan oleh perusahaan tepat dan sesuai dengan daya beli konsumen, maka pemilihan konsumen pada suatu produk tertentu akan dijatuhkan pada produk tersebut.

Rumusan Masalah penelitian ini adalah: 1) Bagaimana pengaruh iklan terhadap keputusan pembelian produk Maybelline di Kota Padang. 2) Bagaimana pengaruh personal selling terhadap keputusan pembelian produk Maybelline di Kota Padang. 3) Bagaimana pengaruh harga terhadap keputusan pembelian produk Maybelline di Kota Padang

\section{LANDASAN TEORI}

Manusia sebagai pembeli pasti menggunakan berbagai pertimbangan dalam membeli atau tidak membeli suatu produk tertentu.Misalnya manfaat barang atau jasa yang dibeli, jangka maktu manfaat tersebut, pemuasan kebutuhan mana yang ingin dipuaskan, apakah yang bersifat primer, sekunder, atau testier.Keputusan pembelian menurut Schiffman dan Kanuk (2008:485), dapat diartikan sebagai pemilihan dari dua atau lebih alternatif pilihan keputusan pembelian.Artinya bahwa seseorang sebelum melakukan pembelian tersedia beberapa alternatif pilihan, sehingga dia harus memilih salah satu diantaranya.Fenomena ini sangat nyata jelas ketika konsumen melakukan pembelian merek untuk pertama kalinya, dan membeli dengan jumlah yang lebih sedikit dari biasanya.Pembelian ini biasa disebut trial purchase. Kemudian setelah sebuah merek telah dicoba dan terbukti memuaskan atau dirasakan lebih baik dibanding dengan merek lainnya maka seorang konsumen biasanya akan melakukan pembelian ulang merek tersebut.

Untuk melakukan penjualan kepada pelanggan perusahaan harus bekerja keras dan bekerja cerdas.Dimana tujuan utama promosi adalah menginformasikan, mempengaruhi dan membujuk serta mengingatkan pelanggan sasaran tentang perusahaan dan bauran pemasarannya.Suatu kegiatan promosi jika dilaksanakan dengan baik dapat mempengaruhi konsumen mengenai dimana dan bagaimana konsumen membelanjakan pendapatannya. 
Promosi merupakan salah satu variable dalam bauran pemasaran yang sangat penting dilaksanakan oleh perusahaan dalam memasarkan produk jasa.Kegiatan promosi bukan saja berfungsi sebagai alat komunikasi antara perusahaan dengan konsumen, melainkan juga sebagai alat untuk mempengaruhi keputusan konsumen sesuai dengan keinginan dan kebutuhannya (Rambat dan Ahamad, 2008: 120).

Iklan atau advertising dapat didefenisikan sebagai bentuk komunikasi non personal mengenai suatu organisasi, produk, servis atau ide yang dibayar oleh satu sponsor yang diketahui.Adapun maksud 'dibayar' pada defenisi tesebut menunjukkan fakta bahwa ruang atauwaktubagi suatu pesan iklan pada umumnya harus dibeli. Maksud kata 'non personal' berarti suatu iklan melibatkan media massa (TV, radio, majalah dan koran) yang dapat mengirimkan pesan kepada sejumlah besarkelompok individu pada saat bersamaan (Morissan, 2010).

Kotler dan Keler (2009:261) menyatakan bahwa "Penjualan personal (personal selling) merupakan presentasi pribadi oleh wiraniaga perusahaan untuk tujuan menghasilkan penjualan dan membangun hubungan pelanggan".Rambat dan Ahmad, (2008: 120) menyatakan bahwa 'Penjualan perseorangan merupakan penjualan melalui perorangan perusahaan sudah berhadapan dengan calon pembeli potensial.Sifat penjualan perorangan dapat dikatakan lebih luwes karena tenaga penjualan dapat secara langsung menyesuaikan penawaran penjualan dengan kebutuhan dan perilaku masing-masing calon pembeli.

Strategi menentukan harga sangat signifikan dalam pemberian nilai kepada konsumen dan mempengaruhi citra produk, serta keputusan konsumen.Penentuan harga juga berhubungan dengan pendapatan dan turut mempengaruhi penawaran atau saluran pemasaran.Akan tetapi hal terpenting adalah keputusan dalam penentuan harga harus konsisten dengan strategi pemasaran secara keseluruhan (Rambat dan Ahmad, 2008: 72).

\section{METODE PENELITIAN}

Jenis penelitian ini adalah penelitian deskriptif kuantitatif.Penelitian ini disebut penelitian deskriptif karena penelitian yang dilakukan dengan tujuan utama untuk memberikan gambaran atau deskripsi tentang suatu keadaan secara objektif. Sukmadinata (2011) penelitian deskriptif adalah suatu metode yang ditujukan untuk menggambarkan fenomena-fenomena yang ada, yang berlangsung pada saat ini atau saat yang lampau.Penelitian kuantitatif merupakan data penelitian yang berbentuk angka atau data kuantitaif yang diinginkan atau scoring (Sugiyono, 2013).Penelitian deskriptif kuantitaif merupakan pengumpulan dan pengukuran data yang berbentuk deskripsi dan angka.

Penelitian ini penulis lakukan di Kota Padang.Objek penelitian hanya dibatasi pada konsumen yang telah membeli produk kosmetik merek Maybelline.Sedangkan waktu penelitian dilakukan pada bulan Desember 2017 sampai dengan selesai.

Dalam suatu kegiatan baik yang bersifat ilmiah maupun yang bersifat sosial, perlu dilakukan pembatasan populasi dan cara pengambilan sampel. Sampel yang diambil unsur-unsurnya harus representatif artinya dapat mewakili keseluruhan dari populasi.Menurut Sekaran (2006:121), populasi mengacu pada keseluruhan kelompok orang, kejadian, atau hal minat yang ingin peneliti investigasi.Di dalam penelitian ini yang menjadi populasi adalah seluruh konsumen yang mengetahui dan memiliki keinginan untuk membeli produk kosmetik merek Maybelline di Kota Padang yang jumlahnya tidak diketahui.

Sampel adalah sebagian dari populasi.Sampel terdiri atas sejumlah anggota yang dipilih dari populasi (Sekaran, 2006: 123). Metode pengambilan sampel yang di gunakan dalam penelitian ini dengan menggunakan carapurposive sampling, yaitu dalam mengambil sampel dasar berdasarkan kriteria tertentu. Kriteria pengambilan sampel adalah: a) Berusia di atas 20 tahun, b)Belum membeli tapi mengetahui informasi tentang produk 
kosmetik Maybelline. c) Memiliki keinginan untuk membeli produk kosmetik Maybelline. d) Bertempat tinggal atau berdomisili di Kota Padang.

\section{HASIL PENELITIAN DAN PEMBAHASAN}

Data yang di peroleh dalam penelitian ini akan dianalisis dengan menggunakanmetode statistik untuk menguji hipotesis dan variabel yang di gunakan. Data tersebut dianalisis dengan menggunakan SPSS (Statistical Program for Science) versi 16.0. Uji regresi linear berganda merupakan teknik statistik yang digunakan untuk menguji pengaruh beberapa variabel bebas terhadap variabel terikat (Sekaran, 2006). Hasil analisis regresi linier berganda dapat diringkas pada Tabel 4.15 berikut ini:

\section{Ringkasan Hasil Analisis Regresi Linier} Berganda

\begin{tabular}{|l|c|c|c|}
\hline $\begin{array}{c}\text { Konstanta } \\
\text { dan } \\
\text { Variabel } \\
\text { Bebas }\end{array}$ & $\begin{array}{c}\text { Koefisien } \\
\text { Regresi }\end{array}$ & $\begin{array}{c}\text { Signif } \\
\text { ikan }\end{array}$ & $\begin{array}{c}\text { Keterang } \\
\text { an }\end{array}$ \\
\hline Konstanta (a) & 0.275 & 0.144 & - \\
\hline (X1) & 0.383 & 0.000 & $\begin{array}{c}\text { H1 } \\
\text { Terbukti }\end{array}$ \\
\hline (X2) & 0.422 & 0.000 & $\begin{array}{c}\text { H2 } \\
\text { Terbukti }\end{array}$ \\
\hline (X3) & 0.229 & 0.051 & $\begin{array}{c}\text { H3 Tidak } \\
\text { Terbukti }\end{array}$ \\
\hline
\end{tabular}

Sumber: Olahan Data SPSS, 2017.

Berdasarkan hasil analisis regresi linier berganda yang disajikan pada tabel diatas, berikut ini dapat dikemukakan persamaan regresi linier berganda:

$$
Y=0,275+0,383 X_{1}+0,422 X_{2}+0,229 X_{3}
$$

Koefisisen regresi masing-masing variabel penelitian dapat diartikan sebagai berikut:

Nilai konstanta sebesar 0,275 berarti tanpa adanya pengaruh dari variabel bebas maka nilai variabel terikat hanya sebesar 0,275. Hal ini berarti bahwa apabila variabel bebas nilainya konstan (periklanan, personal selling dan harga), maka nilai variabel keputusan pembelian hanya sebesar 0,275 .

Besaran koefisien regresi variabel periklanan bernilai positif bermakna jika variabel periklanan mengalami kenaikan maka keputusan pembelian akan mengalami peningkatan. Koefisien bernilai positif artinya terjadi hubungan positif antara periklanan dengan keputusan pembelian, semakin baik periklanan maka keputusan pembelian akan semakin tinggi. Besaran koefisien regresi variabel periklanan adalah 0,383 satuan. Hal ini bermakna bahwa jika terjadi peningkatan periklanan sebesar satu satuan dengan asumsi variabel personal selling dan harga tetap, maka akan meningkatkan keputusan pembelian sebesar 0,383 satuan.

Besaran koefisien regresi variabel personal selling bernilai positif bermakna jika variabel personal selling mengalami kenaikan maka keputusan pembelian akan mengalami peningkatan. Koefisien bernilai positif artinya terjadi hubungan positif antarapersonal selling dengan keputusan pembelian, semakin baik personal selling maka keputusan pembelian akan semakin tinggi. Besaran koefisien regresi variabel personal selling adalah 0,422 satuan. Hal ini bermakna bahwa jika terjadi peningkatan personal selling sebesar satu satuan dengan asumsi variabel periklanan dan harga tetap, maka akan meningkatkan keputusan pembelian sebesar 0,422 satuan.

Besaran koefisien regresi variabel harga bernilai positif bermakna jika variabel harga mengalami kenaikan maka keputusan pembelian akan mengalami peningkatan. Koefisien bernilai positif artinya terjadi hubungan positif antara harga dengan keputusan pembelian, semakin pantas harga yang ditawarkan maka keputusan pembelian akan semakin tinggi. Besaran koefisien regresi variabel harga adalah 0,229 satuan. Hal ini bermakna bahwa jika terjadi peningkatan harga sebesar satu satuan dengan asumsi variabel periklanan dan personal sellingtetap, maka akan meningkatkan keputusan pembelian sebesar 0,229 satuan. 
Berdasarkan hasil pengolahan data terlihat bahwa variabel periklanan memiliki nilai signifikansi sebesar 0,000 tahapan pengujian dilakukan dengan menggunakan tingkat kesalahan sebesar 5\% (0,05), dengan demikian terlihat bahwa nilai signifikansi 0,000 lebih kecil dari alpha 0,05, maka keputusannya adalah Ho di tolak dan Ha diterima. Jadi dapat disimpulkan bahwa periklanan berpengaruh positif dan signifikan terhadap keputusan pembelian produk kosmetik Maybelline di Kota Padang.

Menurut Kotler dan Keller (2009:356) keputusan pembelian dipengaruhi oleh rangsangan pemasaran yang terdiri dari bauran promosi. Kotler dan Keller (2009), menyatakan bahwa periklanan adalah semua bentuk terbayar atas presentasi nonpribadi dan promosi ide, barang atau jasa oleh sponsor yang jelas. Iklan bisa menjadi cara yang efektif dari segi biaya untuk mendistribusikan pesan, baik dari tujuan membangun preferensi merek atau mendidik orang. Bahkan dalam lingkungan media yang penuh tantangan saat ini, iklan yang baik akan menghasilkan hasil yang memuaskan.

Menurut Schiffman dan Kanuk (2008:8), perilaku keputusan konsumen dipandang sebgai tiga tahap yang berbeda, namun berhubungan satu sama lain: Tahap masukan mempengaruhi pengenalan konsumen terhadap keputusan atas produk dan terdiri dari dua sumber informasi utama: usaha pemasaran perusahaan (produk, promosi, harga dan dimana dijualnya).

Hasil penelitian ini sejalan dengan hasil penelitian terdahulu yang dilakukan oleh Windusara dan Kusuma(2015) dengan judul penelitian Pengaruh Bauran Promosi Terhadap Keputusan Pembelian Oppo Smartphone.Dimana hasil penelitian menunjukkan bahwa periklanan dan penjualan pribadi berpengaruh positif dan signifikan terhadap keputusan pembelian pada konsumen oppo smartphone. Indikator yang paling dominan berpengaruh positif dalam variabel periklanan adalah pesan yang terkandung dalam berbagai media (televisi) dapat dipercaya.

Penelitian lain yang dilakukan oleh Michael Lontoh. (2016) dengan judul penelitian
Analisis Pengaruh Bauran Promosi Terhadap Keputusan Pembelian Mobil Toyota Pada Pt. Hasjrat Abadi Manado Cabang Tendean. Hasil Penelitian Menunjukan Secara Simultan Bahwa Penjualan Pribadi, Periklanan, Promosi Penjualan, Hubungan Masyarakat Dan Pemasaran Langsung Berpengaruh Secara Signifikan Terhadap Keputusan Pembelian. Secara Parsial Penjualan Pribadi, Periklanan, Promosi Penjualan, Hubungan Masyarakat Dan Pemasaran Langsung Berpengaruh Signifikan Terhadap Keputusan Pembelian.

Berdasarkan hasil pengolahan data terlihat bahwa variabel personal selling memiliki nilai signifikansi sebesar 0,000 tahapan pengujian dilakukan dengan menggunakan tingkat kesalahan sebesar 5\% $(0,05)$, dengan demikian terlihat bahwa nilai signifikansi 0,000 lebih kecil dari alpha 0,05, maka keputusannya adalah Ho di tolak dan $\mathrm{Ha}$ diterima. Jadi dapat disimpulkan bahwa personal selling berpengaruh positif dan signifikan terhadap keputusan pembelian produk kosmetik Maybelline di Kota Padang.

Menurut Kotler dan Keller (2009:356) keputusan pembelian dipengaruhi oleh rangsangan pemasaran yang terdiri dari bauran promosi. Kotler dan Keler (2009:261) menyatakan bahwa "Penjualan personal (personal selling) merupakan presentasi pribadi oleh wiraniaga perusahaan untuk tujuan menghasilkan penjualan dan membangun hubungan pelanggan". Rambat dan Ahmad, (2008: 120) menyatakan bahwa "Penjualan perseorangan merupakan penjualan melalui perorangan perusahaan sudah berhadapan dengan calon pembeli potensial. Sifat penjualan perorangan dapat dikatakan lebih luwes karena tenaga penjualan dapat secara langsung menyesuaikan penawaran penjualan dengan kebutuhan dan perilaku masing-masing calon pembeli.

Penelitian ini sejalan dengan penelitian yang dilakukan oleh Michael Lontoh. (2016) dengan judul penelitian Analisis Pengaruh Bauran Promosi Terhadap Keputusan Pembelian Mobil Toyota Pada Pt. Hasjrat Abadi Manado Cabang Tendean. Hasil 
Penelitian Menunjukan Secara Simultan Bahwa

Penjualan Pribadi, Periklanan, Promosi

Penjualan, Hubungan Masyarakat Dan

Pemasaran Langsung Berpengaruh Secara

Signifikan Terhadap Keputusan Pembelian.

Secara Parsial Penjualan Pribadi, Periklanan, Promosi Penjualan, Hubungan Masyarakat Dan Pemasaran Langsung Berpengaruh Signifikan Terhadap Keputusan Pembelian.

Penelitian lain yang dilakukan oleh Agustina M. Kaeng, dkk. (2014) dengan judul penelitian Bauran Promosi Pengaruhnya Terhadap Keputusan Pembelian Motor Yamaha Di Pt. Hasjrat Abadi.Secara parsial periklanan, promosi penjualan, pemasaran langsung, penjualan pribadi dan hubungan masyarakat berpengaruh terhadap keputusan pembelian. Manajemen perusahaan sebaiknya terus menyempurnakan dari kualitas produk secara keseluruhan dengan membuat inovasi-inovasi baru agar dapat meningkatkan penjualan sehingga dapat menentukan strategi pemasaran yang baik demi kemajuan perusahaan.

Dari hasil olahan data yang dapat dilihat pada Tabel 4.18, diketahui bahwa dari pengujian Koefisien Determinasi terlihat nilai koefisen determinasi adalah sebesar 0,896 atau sama dengan 89,6\%. Hasil tersebut memperlihatkan bahwa dari keputusan pembelian yang dapat dijelaskan oleh periklanan, personal selling dan hargasebesar $89,6 \%$, sedangkan sisanya $10,4 \%$ diduga dijelaskan oleh faktor-faktor lain yang tidak diteliti dalam penelitian ini. Menurut Kotler dan Keller (2009:356) keputusan pembelian dipengaruhi oleh rangsangan pemasaran yang terdiri dari distribusi, serta psikologi konsumen yang terdiri dari motivasi, persepsi, pembelajaran, keyakinan dan sikap. Karakteristik konsumen yang mencakup budaya, sosial, dan personal. Sedangkan menurut Tjiptono (2009:8), salah satu faktor yang mempengaruhi perilaku pembelian konsumen adalah branding. Kebijakan dan prosedur branding menyangkut: pemilihan merek dagang, kebijakan merek, dan penjualan melalui private label atau tanpa merek.

\section{PENUTUP}

\section{Kesimpulan}

Bedasarkan hasil penelitian dan pembahasan maka dapat disampaikan beberapa kesimpulan penelitian sebagai berikut:

1. Periklanan berpengaruh signifikan terhadap keputusan pembelian produk kosmetik Maybelline di Kota Padang. Berdasarkan hasil pengolahan data dapat diketahui bahwa rerata variabel periklanan adalah 3,24 dengan TCR sebesar 64,9\%. Hal ini bermakna bahwa periklanan termasuk ke dalam kategori kurang baik.

2. Personal selling berpengaruh signifikan terhadap keputusan pembelian produk kosmetik Maybelline di Kota Padang. Berdasarkan hasil pengolahan data dapat diketahui bahwa rerata variabel personal selling adalah 3,70 dengan TCR sebesar $74,1 \%$. Hal ini bermakna bahwa personal selling termasuk ke dalam kategori cukup baik.

3. Harga tidak berpengaruh terhadap keputusan pembelian produk kosmetik Maybelline di Kota Padang. Berdasarkan hasil pengolahan data dapat diketahui bahwa rerata variabel harga adalah 3,49 dengan TCR sebesar 69,9\%. Hal ini bermakna bahwa harga termasuk ke dalam kategori cukup wajar

4. Periklanan, personal selling, dan harga secara simultan berpengaruh signifikan terhadap keputusan pembelian produk kosmetik Maybelline di Kota Padang.

5. Dari hasil olahan data, diketahui bahwa dari pengujian Koefisien Determinasi sebesar 0,896 atau sama dengan 89,6\%. Hasil tersebut memperlihatkan bahwa dari keputusan pembelian yang dapat dijelaskan oleh periklanan, personal selling dan hargasebesar 89,6\%, sedangkan sisanya $10,4 \%$ diduga dijelaskan oleh faktor-faktor lain yang tidak diteliti dalam penelitian ini.

6. Dari analisis regresi linier berganda, ditemukan bahwa periklanan, personal selling, dan harga berpengaruh positif terhadap keputusan pembelian produk kosmetik Maybelline di Kota Padang. 


\section{Keterbatasan dan Saran Penelitian}

Peneliti menyadari bahwa penelitian yang telah berhasil dilaksanakan ini masih memiliki beberapa kekurangan yang disebabkan adanya keterbatasan yang peneliti miliki selama pembuatan skripsi ini. Keterbatasan tersebut meliputi:

1. Penelitian ini hanya menganilisis periklanan, personal selling, dan harga, dan masih adanya variabel lain diluar model penelitian yang mempengaruhi terbentuknya keputusan pembelian konsumen pada produk kosmetik Maybelline di kota Padang yang tidak digunakan dalam penelitian ini. Bagi peneliti selanjutnya yang tertarik mengangkat judul yang sama dengan penelitian ini penulis menyarankan agar menambah variabel lain untuk dibuktikan dalam penelitian tersebut. Hal ini dilakukan agar hasil penelitian yang ditemukan bisa menutupi kekurangan yang terdapat dalam penelitian ini.

2. Objek penelitian ini hanyalah konsumen yang membeli produk kosmetik Maybelline,

\section{DAFTAR PUSTAKA}

Ali Hasan.2013. Marketing dan Kasus-Kasus Pilihan. CAPS

Eko Putro Widoyoko. 2012. Teknik Penyusunan Intrumen Penelitian. Yogyakarta: Pustaka Belajar.

Fandy Tjiptono. 2011. Manajemen \& Strategi Merek. Yogyakarta: Andi Offset.

Hidayati, R. R., \& Marlius, D. (2018). Aktivitas Promosi Dalam Meningkatkan Dana Pihak Ketiga Pada PT. Bank Perkreditan Rakyat (BPR) Batang Kapas Pesisir Selatan.

https://doi.org/10.31227/osf.io/8d gqn jadi disarankan bagi peneliti selanjutnya untuk dapat mengambil objek penelitian yang lain agar kajian tentang periklanan, personal selling, dan harga serta keputusan pembelian dapat dipahami secara mendalam.

3. Sulitnya bagi peneliti untuk menentukan sampel yang benar dapat mewakili seluruh populasi sehingga mempengaruhi hasil yang ditemukan didalam penelitian ini. Bagi peneliti selanjutnya disarankan untuk mampu mencoba memperbanyak jumlah responden dan lebih selektif dalam memilih calon responden, saran ini penting untuk meningkatkan mutu dan kualitas hasil penelitian.

4. Metode analisis data dalam penelitian ini menggunakan metode analisis regresi linier berganda, jadi disarankan bagi peneliti selanjutnya untuk dapat menggunakan metode analisis yang lain agar kajian tentang produk, dan promosi serta keputusan pembelian dapat dipahami secara mendalam.

Husein Umar.2013.Metode Penelitian Untuk Skripsi dan Tesis Bisnis. PT. Raja Grafindo: Jakarta

Knapp, E Duane.2002.The Brand Mindset.Yogyakarta: Andi.

Kotler, Philip dan Armstrong. 2008. Prinsipprinsip Pemasaran .Jilid 1.Edisis 12. Erlangga: Jakarta.

Kotler, Philip dan Keller, Kevine. Lane.2009. Manajemen Pemasaran. Jilid 2. Edisi 13. Erlangga: Jakarta.

Marlius, D. (2016). Pengaruh Bauran Pemasaran Jasa Terhadap Minat Nasabah Dalam Menabung Pada Bank Nagari Cabang Muaralabuh. https://doi.org/10.31227/osf.io/vdqgx 
Marlius, D. (2017). Keputusan Pembelian Berdasarkan Faktor Psikologis Dan Bauran Pemasaran Pada PT. Intercom Mobilindo Padang. Jurnal Pundi. Volume 1. No. 1. Hal. 57-66. https:/doi.org/10.31575/jp.v1 i1.9

Morissan.2010.Periklanan:

Komunikasi Pemasaran Terpadu. Jakarta: Kencana

Mowen, J.C dan Minor, M. 2002. Perilaku Konsumen. Jilid 2, Edisi Kelima. Penerbit: Erlangga, Jakarta.

Nyoman Dantes.2012.Metode

Penelitian. Yogyakarta: Andi Offset

Schiffman, Leon. G dan Leslie L. Kanuk. 2008. Perilaku Konsumen. Penerbit: Indeks, Jakarta.

Rambat Lupiyoadi dan Ahmad Hamdani, A. 2009. Manajemen Pemasaran Jasa. Jakarta: Penerbit Salemba Empat.

Sekaran, Uma. 2006. Research Methods For Business, Edisi Keempat. Penerbit: Salemba Empat, Jakarta.

Sugiyono. 2013. Metode Penelitian Manajemen, Cetakan Pertama, Penerbit: Alfabeta, Bandung.

Suharsimi Arikunto. 2010. Prosedur Penelitian: Suatu Pendekatan Praktek. Edisi Revisi V. Jakarta: Rineka Cipta.

Susanti, F. (2015). Pengaruh Bauran Promosi Terhadap Keputusan Klien Dalam Memilih Radio Carano Sebagai Media Promosi Iklan. https://oi.org/10.31227/osf.io/b9ws7

Susanti, F. (2014). Pengaruh Tarif Iklan Terhadap Pendapatan Pada PT. Radio Swara Carano Batirai Indah Batusangkar. https://doi.org/10.31227/osf.io/dy863
Agustina M. Kaeng, dkk. 2014. Bauran Promosi Pengaruhnya Terhadap Keputusan Pembelian Motor Yamaha Di Pt. Hasjrat Abadi. Jurnal Emba 1077 Vol.2 No.3 September 2014, Hal. 10771088

Ari Wibowo. 2014. Pengaruh Kualitas Layanan, Harga Dan Lokasi Terhadap Keputusan Pembelian Di 'D'stupid Baker" Surabaya. Jurnal Ilmu \& Riset Manajemen Vol. 3 No. 12 (2014)

Dewa Bagus Nugraha Windusara dan A.A. Gd Agung Artha Kusuma. 2015. Pengaruh Bauran Promosi Terhadap Keputusan Pembelian Oppo Smartphone. E-Jurnal Manajemen Unud, Vol. 4, No. 12, 2015: 4160 - 4185 Issn : 2302-8912 4160

Fira Dinan1,dkk. 2016. Analisis Faktor-Faktor Yang Memengaruhi Keputusan Pembelian Produk Kosmetik Oriflame Pada Mahasiswi Universitas Muhammadiyah Jember. Jurnal Manajemen Dan Bisnis Indonesia Vol 2. No. 1 Juni 2016

Michael Lontoh. 2016. Analisis Pengaruh Bauran Promosi Terhadap Keputusan Pembelian Mobil Toyota Pada Pt. Hasjrat Abadi Manado Cabang Tendean. Jurnal Berkala Ilmiah Efisiensi Volume 16 No. 01 Tahun 2016 